\title{
Judicial Remedies for Forced Slum Evictions in Bangladesh: An Analysis of the Structural Injunction
}

\author{
S M Atia NAZNIN* \\ Macquarie Law School, Macquarie University; School of Law, BRAC University \\ Shawkat ALAM** \\ Macquarie Law School, Macquarie University; Centre for Environmental Law, Macquarie University
}

\begin{abstract}
The adoption of weak remedies, such as declarations or recommendations by the Bangladesh Supreme Court in litigations on state-induced forced slum evictions, significantly contributes to the tardy implementation of court orders. In this context, there is a growing global consensus on the structural injunction - a remedy that enables judges to monitor and bring about governmental compliance with judicial orders of social rights litigation. The Bangladesh Supreme Court faces several real and compelling challenges relating to its constitutional authority and institutional capacity that hinder remedial innovation. Through examining relevant constitutional provisions, judicial approach, and comparative examples, this article argues that the court has the capacity to overcome these constraints. Thus, it advocates judicial reform in Bangladesh to offset the state's often arbitrary interference with the basic necessity of housing of the slum dwellers.
\end{abstract}

Keywords: forced slum evictions, judicial remedies, public interest litigation, structural injunction, basic necessity of housing

\section{INTRODUCTION}

Under the Constitution of Bangladesh, housing or shelter has not traditionally been considered a right, but a basic necessity and one of the fundamental principles of state policy. The Constitution is explicit about the non-justiciability of the provision of housing as well as other necessities like food, clothing, education, and medical care. ${ }^{1}$ The state, however, has an international obligation to ensure housing for all, with special attention required for the

* LL.B. with Honours (Dhaka University, Bangladesh), LL.M. (Dhaka University, Bangladesh), Master of Human Rights and Democratisation (University of Sydney, Australia). $\mathrm{PhD}$ in Law Candidate, Macquarie University, Australia, and Lecturer, School of Law, BRAC University, Bangladesh. Correspondence to S. M. Atia Naznin, Room: W3A 327, Macquarie Law School, Macquarie University, Macquarie Park, NSW 2109, Australia. E-mail address: s-m-atia.naznin@ @students.mq.edu.au. ** LL.B. with Honours (Rajshahi University, Bangladesh), LL.M. (Dhaka University, Bangladesh), PhD (Macquarie University, Australia), Professor, Macquarie Law School, and Director, Centre for Environmental Law, Macquarie University, Australia. Correspondence to Dr Shawkat Alam, Professor, Macquarie Law School, Director, Centre for Environmental Law, Office: W3A 440, Macquarie Law School, Macquarie University, Macquarie Park, NSW 2109, Australia. E-mail address: shawkat.alam@mq.edu.au. The authors are grateful to the anonymous reviewers for their constructive comments on a draft of this article.

1. Constitution of the People's Republic of Bangladesh, Arts. 8(2) and 15(a). 
disadvantaged individual or community. ${ }^{2}$ The outcomes of recent public interest litigations (PILs) on slum evictions also suggest that judicial consideration of the basic necessity of housing as a core component of the justiciable right to life is evolving. However, domestically, the prevalence of inadequate legislative and policy measures severely jeopardizes the capacity of the state to fulfil its obligations and undermines the gains of the courts to date. ${ }^{3}$

This problem is further aggravated by the systematic and state-induced forced demolitions of slums that started even before the birth of the country in 1971. To ameliorate this situation, since the late 1990s, several local non-governmental and human rights organizations have started to file petitions on behalf of impoverished slum dwellers. Alongside their efforts, the Supreme Court of Bangladesh has taken a forward-looking approach by issuing orders against the government to stop hostile slum demolitions. Various agencies have widely applauded the rulings of the court for recognizing slum dwellers' need for housing as integral to their right to life and livelihood, and for directing the government to make arrangements for resettlement before any eviction attempt. ${ }^{4}$

However, critics argue that these decisions have achieved only symbolic justice by failing to improve the status quo of the evicted slum dwellers. The steady flow of cases on slum evictions reflects the continued eviction practice in Bangladesh and indicates that the state is still far from fulfilling its obligations under international and national human rights instruments that recognize the right to housing and prohibit forced evictions. Continued non-compliance with the court orders by government authorities due to a gross lack of political will has been identified as the major factor contributing to this failure. ${ }^{5}$

Successful implementation of progressive social rights judgments largely depends on the nature of judicial remedies as well as the sociopolitical and legal contexts, such as courts' legitimacy in society, political will, states' implementation capacity, authority of judicial decisions, and vigilance of the litigants. ${ }^{6}$ Although the political branch of the government is the principal organ for implementing courts' decisions, judicial remedies can nevertheless play a complementary role in influencing political compliance. In this context, in comparison to traditional remedies such as declarations, recommendations, damages, or negative injunctions, legal scholars and judicial practices in numerous jurisdictions, as discussed in this article, suggest a preference for the structural injunction or retention of judicial supervision to effectively influence the implementation of court orders.

While the conventional remedial strategies in social rights litigation constitute only oneshot or monologic remedies, continued judicial monitoring throughout the implementation of a court order creates a space for dialogue and collaboration between the court and the

2. Bangladesh has signed and ratified the key international human rights instruments that recognize the right to housing and prohibit forced eviction. The most significant among them are the ICESCR, UNCRC, CEDAW, Istanbul Declaration on Human Settlements 1996, and the Global Strategy for Shelter to the Year 2000.

3. To date, Government and Local Authority Lands and Buildings (Recovery of Possession) Ordinance 1970 is the only notable legislative effort on forced evictions to deal with the procedural protection to the evictees. The National Housing Policy 1993 (as amended in 1999, 2004, and 2008) for the first time evinces support for housing for the impoverished. The policy has been followed by the Draft National Housing Policy of 2016, which has yet to be passed. See National Housing Policy 1993 (Bangladesh) (Housing Policy), Government and Local Authority Lands and Buildings (Recovery of Possession) Ordinance 1970 (Bangladesh) (Bangladesh Lands and Buildings Ordinance), and Draft National Housing Policy 2016 (Bangladesh).

4. Hossain (2005), pp. 13-15.

5. Langford (2009), p. 106; Ain o Salish Kendra (2012), p. 20; Pereira (2014), pp. 70-2.

6. Gloppen (2008), pp. 343-5. 
policy-makers. ${ }^{7}$ Thus, it enables the judiciary to prevent the executive from taking arbitrary ownership of the social rights delivery system by infringing people's rights, liberty, dignity, or freedom, through either retrogressive action or gross resistance. ${ }^{8}$

The Supreme Court of Bangladesh has yet to adopt this remedy in litigations on forced slum evictions. It rather orders weak remedies like declarations and recommendations, which are deficient in monitoring compliance. Since the implementation of court orders is reflective of the strength of judicial decisions, ${ }^{9}$ this problem of non-implementation becomes concerning, indicating that weak remedies contribute to the non-implementation of the court orders in forced slum eviction litigations, as has been the case in other jurisdictions. ${ }^{10}$

Notwithstanding the benefits to be gained from the remedy of the structural injunction, it is not a perfect remedy. Indeed, its increased application by the courts should be approached with an understanding of the potential impediments that could operate to limit its success as a method of achieving greater social justice. The Bangladesh Supreme Court faces several real and compelling challenges relating to its constitutional authority and institutional capacity that hinder remedial innovation. For example, concerns about the separation of powers, resource scarcity, and the weak protection afforded to housing in the constituional as well as the legislative provisions result in the court's deference to the executive authority. This paper, however, argues that the Bangladesh Supreme Court has the capacity to overcome these challenges. The existence of positive constitutional values on establishing socioeconomic justice, remedial developments in comparative jurisdictions, remedial authority of the court under the constitutional dispensation, and, overall, the adoption of the structural injunction by the court in other rights litigations have provided sufficient impetus for the court's capacity. In support of this key argument, the paper examines both theoretical and practical perspectives on the structural injunction and the court's ability to adopt this remedy in the cases of forced slum evictions.

To contextualize the seriousness of the problem, first, the meaning of forced slum eviction and its nexus with homelessness and the right to adequate housing is illuminated, and dynamics of forced slum evictions in Bangladesh are analyzed. It then delves into a normative and legal analysis of judicial remedies. Following an initial examination of the legislative and policy framework that primarily determines the scope of judicial intervention, this part also discusses the remedial approach of the court in the PILs on forced slum evictions. Lastly, the paper critically analyzes the structural injunction and the challenges before the Bangladesh Supreme Court and, in so doing, reveals the capacity of the court to adopt this remedy.

To date, numerous scholarly studies, mostly descriptive and empirical, have been conducted on forced slum evictions in Bangladesh, their human rights impact, and the legal and policy implications of the issue. Relatively few researchers have focused on the judicial role in combating forced slum evictions and realizing the right to housing of the homeless slum dwellers, and none has comprehensively researched judicial remedy. A few critics have supported the application of the structural injunction remedy, but their critiques deal with the judiciary's role in constitutional rights or basic necessities more generally. This paper, therefore, fills in the current gaps and opens up space for further research on this issue.

7. Wesson (2004), p. 307; for a comparative analysis of judicial remedies, see also Roach (2008).

8. Wesson (2004), pp. 306-7.

9. Gloppen (2006), pp. 35-42.

10. Ahmed (1999), p. 151; Hoque (2006), pp. 410-11. 


\section{UNDERSTANDING FORCED SLUM EVICTIONS IN BANGLADESH}

\subsection{Forced Slum Evictions, Homelessness, and the Right to Adequate Housing: Meaning and Nexus}

Housing today means not merely a roof over one's head or the existence of four walls. It rather contemplates "adequate housing" that requires enabling a person to live a standard life with dignity, peace, and security, such that his or her capability is utilized and expanded. To meet this standard, the components of adequacy must include the presence of legal security of tenure; availability of services, materials, facilities, and infrastructure; affordability; habitability; accessibility; location; and cultural adequacy. ${ }^{11}$

Contrary to the provision of adequate housing, homelessness indicates a situation of deprivation and vulnerability that prevents a person from leading a minimum standard of living. Hence, homelessness is defined by the absence of the components of adequacy contributing to appropriate housing. ${ }^{12}$ Indeed, the eradication of homelessness constitutes a prerequisite for ensuring "adequate shelter for all." A holistic definition of homelessness equates it with "rootlessness" and "resourcelessness" in addition to its traditional and physical understanding as "rooflessness." This is consonant with the subjective conception of home as including both the social and economic aspects, as reflected in the notion of the right to housing. ${ }^{13}$

The term "forced eviction" or "forced slum eviction" seems an apparent tautology, as eviction implies the use of force. However, a deeper analysis of the term reveals that "forced eviction" is nothing but a form of arbitrary displacement, where the evictees, having inferior power status to the authority that carries out the evictions, have very little say in the eviction process and are deprived of legal or other protection. ${ }^{14}$ Lack of protection occurs when there is no arrangement for adequate resettlement and compensation, an absence of due process in carrying out the eviction, a violation of the state's domestic and international human rights obligations on fair eviction, and no scope for challenging the decision or the process of the eviction. ${ }^{15}$ Thus, forced eviction intensifies "inequality, social conflict, segregation and ghettoization" by leading to irreparable discrimination against the already deprived and marginalized individuals or communities. ${ }^{16}$ Consequently, in certain circumstances, an inevitable slum eviction would still be considered forced eviction, even with a court order, if the eviction process does not satisfy the international human rights standards on eviction and the related state obligations. ${ }^{17}$

An appropriate connection among forced evictions, homelessness, and the right to adequate housing may be found in General Comment No. 7 of the United Nations Committee

11. CESCR, Art. 11(1); General Comment No. 4 (1992), paras 7-8.

12. Tipple \& Speak (2005), pp. 341-6.

13. Gafur (2004), pp. 267-9.

14. CESCR, Art. 11(1); General Comment No. 7 (1997), para. 3.

15. UN-Habitat \& UNHCR (2014).

16. Kothari (2007), Annex I, para. 7.

17. UN-Habitat \& UNHCR, supra note 15; Particularly on evictions related human rights obligation, see UN Doc. E/CN.4/Sub.2/1997/7 (Annex); GC No. 4, supra note 11; GC No. 7, supra note 14; Deng (1998), Annex; GA Res 60/ 147 (2005) UN Doc A/RES/60/147 (Annex); Pinheiro (2005), Annex; Schutter (2009), Annex; Kothari, supra note 16 , Annex. 
on Economic, Social and Cultural Rights (CESCR). The Committee observed that "[e]victions should not result in individuals being rendered homeless or vulnerable to the violation of other human rights." ${ }^{18}$ Within the broad range of human rights, the right that is primarily violated and that ultimately affects other human rights is the right to adequate housing. ${ }^{19}$ Thus, forced evictions constitute the primary cause of homelessness and deprivation of the right to adequate housing.

Forced evictions manifestly violate the right to adequate housing, which is prima facie a socioeconomic right, and grossly affect the enjoyment of all human rights. ${ }^{20}$ Because of the indivisibility of civil-political and socioeconomic rights, the exercise of all human rights, ranging from the right to food to the right to life, are dependent on the right to adequate housing. ${ }^{21}$ For this reason, to realize and protect the right to adequate housing, all states are under an obligation, as derived from the international human rights agenda, to refrain from forced evictions. Subject to this obligation, an eviction is justified only in exceptional circumstances, as a last resort. It is lawful only when it strictly follows international human rights standards and is compatible with the principle of reasonableness and proportionality. ${ }^{22}$

The practice of forced evictions is defined as "the permanent or temporary removal against the will of individuals, families and/or communities from the homes and/or land which they occupy, without the provision of, and access to, appropriate forms of legal or other protection. ${ }^{, 23}$ In brief, it is "a method of de-housing," 24 through involuntary displacement of persons from their usual abode. The nexus between forced slum evictions and homelessness can be understood through the nature and scope of homelessness. Evictions mainly affect three groups of people that include, first, the economically and socially marginalized community, second, the poorest, and, third, people who live with insecure tenure. ${ }^{25}$ Slum dwellers, falling into all these categories, singly comprise the most affected group in comparison to other groups, such as women, children, youth, disabled, indigenous people, elderly people, and minorities, either religious or ethnic. ${ }^{26}$ Besides, as to the situations that lead to evictions, slum clearance has been identified as one of the principal types. ${ }^{27}$

\subsection{The Dynamics of Forced Slum Evictions in Bangladesh}

Being an enduring manifestation of poverty, deprivation, social exclusion, and inequality, slums pose a worldwide challenge to humanity and society. Slums or low-income settlements represent an extreme form of homelessness where the inhabitants live without access to basic services and facilities. ${ }^{28}$

\footnotetext{
18. GC No. 7, supra note 14 , para. 16 .

19. UNCHR (1993), para. 1.

20. GC No. 7, supra note 14, para. 4.

21. Kothari, supra note 16, para. 6; Hohmann (2013), p. 1.

22. GC No. 4, supra note 11, para. 18.

23. GC No. 7, supra note 14, para. 3 .

24. OHCHR (1996).

25. GC No. 7, supra note 14, para. 10; Kothari, supra note 16, paras 5-7.

26. Kothari, supra note 16 , para. 6 .

27. UN-Habitat \& OHCHR supra note 15, pp. 3-4.

28. UN-Habitat (2011); Roy et al. (2014).
} 
As in other developing countries, slums in Bangladesh are largely visible in the major urban areas, ${ }^{29}$ as they are considered mainly to be the by-product of rapid urbanization. ${ }^{30}$ It is estimated that $61.6 \%$ of the total urban population in Bangladesh lives in slums, this figure being the highest among all the South Asian countries. ${ }^{31}$ Although the percentage decreased to $55.1 \%$ in $2016,{ }^{32}$ slum people still constitute more than half of the urban population. A 2014 report on slum areas and floating population counted 13,938 slums (592,998 slum households) with 2,227,754 inhabitants in the urban areas of Bangladesh. ${ }^{33}$ From 1997 to 2014, over a period of 14 years, the country saw an increase of $66 \%$ in the number of slums. ${ }^{34}$

Although informal settlements have a long history in Bangladesh, the rise of slums dates back to 1971 when, immediately after independence, a large number of poor and destitute people relocated to all the major cities in search of livelihood and found accommodation in slums. ${ }^{35}$ Alongside urbanization, several push-and-pull factors, such as excessive population growth, rural-urban migration as a result of natural calamities, poverty, and lack of livelihood opportunity, have contributed to the continued influx of the slum population. ${ }^{36}$ In conjunction with unplanned urbanization, these causes have put excessive pressure on limited land resources and have contributed to making housing a challenging need. ${ }^{37}$

Being a poverty trap, slum life is the best indicator of measuring poverty, ${ }^{38}$ and slums constitute the highest deprived places of the urban area. ${ }^{39}$ Therefore, the visible face of urbanization in Bangladesh is rightly characterized as the "urbanization of poverty."40 Poverty being the significant problem typical of slum dwellings, slum settlers in Bangladesh continuously face other challenges relating to the exercise of their rights and their ability to obtain the basic survival needs. The basic need of housing remains the most crucial of the various basic necessities. To those living in slums, however, housing means nothing more than living in squalid and insecure squatter settlements. ${ }^{41}$ Such inadequate housing conditions reveal the country's failure to recognize the right of all persons to housing under the International Covenant on Economic, Social and Cultural Rights (ICESCR) and to fulfil its pledge to take appropriate steps for the progressive realization of this right. Unfortunately, no government has made any notable effort toward providing a sustainable solution to this housing problem. This misfortune has been exacerbated by the repeated instances of forced slum eviction by the government agencies, mostly in the name of development and without any measure of alternative arrangements for resettlement. ${ }^{42}$

29. Bangladesh Bureau of Statistics (2015), p. 3.

30. Rahman (2001); UN-Habitat, supra note 28.

31. Mahbubul Haque Human Development Centre (2014), p. 31.

32. UN-Habitat (2016), p. 204.

33. Bangladesh Bureau of Statistics, supra note 29, pp. 17-26.

34. Ibid., p. 21.

35. Ibid., p. 3.

36. Guhathakurta \& Begum (2005), pp. 199-200.

37. Islam (2006).

38. Baker \& Schuler (2004), pp. 4, 53.

39. UN-Habitat (2007), p. 10.

40. Guhathakurta \& Begum, supra note 36, p. 200.

41. United Nations (2000).

42. Hossain \& Siddiqi (2007), p. 61. 
The history of slum evictions in Bangladesh dates back to before independence, to the mid-1970s. ${ }^{43}$ After independence, the first large-scale eviction took place in $1975 .{ }^{44}$ Since then, there have been numerous instances of slum eviction by successive regimes, especially in Dhaka, where the highest number of slums exists. It is estimated that at least 135 slums were subject to evictions from 1975 to 2005 throughout Bangladesh. ${ }^{45}$ Between 1996 and 2004, across the major cities of Dhaka, Chittagong, and Khulna, the number of slum evictions was 115 , resulting in the displacement of approximately 3 million people. ${ }^{46}$ In Dhaka alone, between May and August 1999, evictions occurred in 44 slums, rendering 19,432 families, consisting of 116,562 slum dwellers, homeless. ${ }^{47}$ Between 2006 and 2008, approximately 60,000 people were evicted from 27 slums. ${ }^{48}$ Outside Dhaka, on 14 October 2014, at least 300 slums were subject to evictions in Chittagong in a one-day attempt. ${ }^{49}$ The actual number of evictions is, in fact, much higher than the official figures suggest, as many cases go unreported. ${ }^{50}$

A human rights analysis of forced slum evictions conceives of evictions as violations of the right to housing and other human rights, the realization of which remains a commitment by the government of Bangladesh. Meanwhile, an economic analysis calculates the costs of evictions arising from the loss of households and assets, and from the negative financial effect on the livelihood of the evictees. Such an analysis considers evictions as impediments to the reduction of extreme poverty, this being one of the core development agendas of the country. ${ }^{51}$ Although all of these harms have long-term effects, the loss and sufferings of the displaced slum dwellers are the most direct and immediate during evictions.

\section{JUDICIAL REMEDIES FOR FORCED SLUM EVICTIONS IN BANGLADESH}

\subsection{Judicial Remedies and Forced Slum Evictions}

The indivisibility, interdependence, and interrelation of rights in the international and domestic human rights jurisprudence, the rise and consolidation of democratic constitutionalism along with the constitutionalization of rights over the last couple of decades have successfully shifted the ideological debate surrounding the justiciability of socioeconomic rights towards the practical discussion on their judicial enforcement. ${ }^{52}$ In the broad realm of socioeconomic rights, the right to adequate housing, as it is now conceived, most evinces this transformation of perspectives. Originating as a soft right under the

43. Paul (2006), p. 568.

44. Islam (2003), p. 581.

45. World Bank (2007), pp. 42, 132.

46. UNDP (2013).

47. Centre on Housing Rights and Evictions (COHRE) \& Asian Coalition for Housing Rights (ACHR) (2000), pp. 19,36 .

48. Dustha Shasthya Kendra and Shiree (2011), p. 1.

49. Dhakatribune.org (2014).

50. Rahman, supra note 30, p. 53.

51. For some case-studies on the economic impact of slum evictions, see UNDP, supra note 46; Dustha Shasthya Kendra and Shiree, supra note 48.

52. Shetreet (1988); Porter (2005), p. 43; Melish (2006), p. 173. 
Universal Declaration of Human Rights (UDHR) and later reaffirmed by the ICESCR, it has been widely incorporated into the core international and regional human rights instruments as well as in numerous national Constitutions, laws, and policies, attracting varying levels of protection. While realization of this right, as an integral component of the right to life, promotes the availability of housing for all persons and protects the interests of disadvantaged social groups, its exercise precludes forced evictions. ${ }^{53}$

Over time, both of these aspects have come to attain a more concrete shape as a result of their acknowledgement by the national courts of numerous jurisdictions adjudicating on forced evictions. These courts have accommodated the view that evictions primarily affect the right to housing of the most vulnerable sections of society. Contemporary contestation concerning the right to housing and protection from forced evictions, like other social rights, therefore, is more about the "technical and jurisdictional issues" of the adjudication process and concentrates on the proper judicial role, as largely expressed through judicial remedies. ${ }^{54}$

Forced slum evictions violate the right to adequate housing, which is primarily categorized as a right of socioeconomic type. The UDHR explicitly states that "[e]veryone has the right to an effective remedy by the competent national tribunals for acts violating the fundamental rights granted to him by the constitution or by the law." 55 As the declaration universally applies to all rights, without drawing any division between civil-political and socioeconomic rights, an effective remedy as contemplated by it logically embraces both sets of rights. Furthermore, the CESCR emphasizes that, irrespective of the domestic jurisdiction concerning the justiciability of social rights, courts are capable of adjudicating these rights or, at the very least, their minimum content. ${ }^{56}$ Thus, there exists recognition for judicial remedies.

Critics of judicial remedies for socioeconomic rights violations, however, argue that judges are ill-equipped to adjudicate violations of social rights, as this would exceed their constitutional authority and institutional capacity. Ordinarily, the executive organ of the government is the proper authority on this, and anything otherwise throws undesirable confusion over the judicial role. ${ }^{57}$ These critics also contend that the effective remedies do not necessarily mean judicial remedies. They rather prefer alternatives to judicial remedies, such as administrative remedies, legislative responsiveness to public advocacy campaigns, or reports by the Human Rights Commissions, believing that these avenues provide greater flexibility and responsiveness than formal court-based adjudication for ensuring successful social rights litigation. ${ }^{58}$

However, in conceding the insufficiency of these alternatives, the CESCR insists on the availability of judicial remedies as a viable option. As the CESCR reiterates:

By the same token, there are some obligations, such as (but by no means limited to) those concerning non-discrimination, in relation to which the provision of some form of judicial

53. GA Res 217A (III) (1948) UN Doc A/810, 71 (Art. 25.1); GC No. 4, supra note 11, para. 18.

54. Melish, supra note 52, p. 173 who states that "the technical and jurisdictional issues that accompany case-based litigation in the human rights filed: system-specific justiciability doctrine, admissibility requirements, appropriate balancing tests, remedial deference and supervision of compliance with final orders or settlements."

55. UDHR, supra note 53, Art. 8.

56. CESCR (1998), General Comment No. 9 (1998), para. 2.

57. Cross (2001), pp. 887-93; Michelman (2003), p. 15.

58. Steiner et al. (2008), p. 313. 
remedy would seem indispensable in order to satisfy the requirements of the Covenant. In other words, whenever a Covenant right cannot be made fully effective without some role for the judiciary, judicial remedies are necessary. ${ }^{59}$

The committee further asserts that, as for civil and political rights, judicial remedies are essential for socioeconomic rights. Any discrepancy would, therefore, drastically curtail courts' ability to protect the rights of the most marginalized segment of society. ${ }^{60}$

Thus, slum dwellers either forcibly evicted or living under threats of eviction should have the right of access to timely and appropriate remedies, including judicial remedies. ${ }^{61}$ Given the fact that, just like other rights, the right to housing "can be effectively enforced through sustainable and meaningful remedies" 62 and that "the ineffectiveness of the court orders or decisions is substantially determined by the assurance that they will be enforced," 63 scope for judicial remedial intervention to vindicate forced slum evictions is warranted.

\subsection{Legislative Basis of Judicial Remedies for Forced Slum Evictions in Bangladesh}

In Bangladesh, the provision for housing has a weak constitutional status. It is placed in the chapter on fundamental principles of state policy of the Constitution and is termed as a basic necessity of life, instead of being recognized as a right. ${ }^{64}$ Furthermore, an explicit constitutional bar on its justiciability exists, as the fundamental principles "shall not be judicially enforceable."65

These constitutional limitations perhaps contribute to the inadequate domestic legal framework for the protection of slum dwellers from forced eviction. At the time of writing, the Government and Local Authority Lands and Buildings (Recovery of Possession) Ordinance 1970 remains the only law on eviction to the extent that it deals with removing unauthorized tenants. These tenants are persons who have no legal title to the lands or buildings and who, therefore, unlawfully remain in possession of their dwellings without permission from the designated government authority. ${ }^{66}$ Whenever any eviction attempt occurs, they are entitled to 30 days' notice as a due process requirement of lawful evictions. ${ }^{67}$ Slum dwellers, having no legal ownership over their residences in most cases, meet the criteria for illegal occupants. However, as the ordinance is only limited to government-owned areas, its procedural protection does not cover slum dwellers living on private land and buildings.

Notwithstanding the absence of legislation dealing with evictions, the National Housing Policy 1993 represents the first policy initiative to provide substantive protection to slum dwellers. It does so by prioritizing housing for the poor and the prevention of evictions in the absence of alternative accommodation. ${ }^{68}$ This policy has been subsequently reaffirmed by

\footnotetext{
59. GC No. 9, supra note 56, para. 9.

60. Ibid., para. 10.

61. Kothari, supra note 16, para. 59.

62. Khosla (2010), p. 740.

63. Pheko and Others v. Ekurhuleni Metropolitan Municipality [2012] 42 SA 598 (CC), para. 1.

64. Bangladesh Constitution, Art. 15.

65. Ibid., Art. 8(2).

66. Bangladesh Lands and Buildings Ordinance, supra note 3, s. 2(f).

67. Ibid., ss. 3-5.

68. National Housing Policy (Bangladesh), supra note 3, para. 5.7.1 states that: "the government would take steps to avoid forcible relocations or displacement of slum dwellers as far as possible ... encourage in situ upgrading, slum renovation and progressive housing developments with conferment of occupancy rights, wherever possible, and to undertake relocation with community involvement for clearance of priority sites in the public interest."
} 
the Draft National Housing Policy 2016. However, the policy has not been passed yet and being not a law, it has no binding legal effect.

The inadequacy of these protection measures lies in stark contrast to the Constitution, which envisions a socialist state that strives to achieve economic and social justice with an emphasis on equality, fundamental human rights, and freedom. ${ }^{69}$ After all, Bangladesh is a State Party to the core international human rights instruments that envisage the protection of different aspects of social rights such as, the ICESCR, the Convention on the Rights of the Child, the Convention on the Elimination of All Forms Discrimination Against Women, the Istanbul Declaration of Human Settlement 1996, and a signatory to the Global Strategy for Shelter to the Year 2000. Thus, the country has recognized housing as a human right and committed to taking effective measures to prevent unlawful evictions.

Having borne witness to the unbearable miseries of the evicted and homeless slum dwellers since the late 1990s, numerous human rights and non-governmental organizations have started to challenge the arbitrary evictions by government agencies through PILs. As mentioned above, under the constitutional scheme, the violation of the basic necessity of housing due to forced slum evictions cannot be litigated in the courts. The legislative protection of the substantive right of the slum dwellers to be protected from evictions is, moreover, shabby. So what has facilitated these organizations' attempts to litigate forced slum evictions?

Three intertwined factors have been key to catalyzing their efforts. The first is the presence of the justiciable right-to-life clause in the Constitution as one of the fundamental rights. ${ }^{70}$ The litigating organizations have successfully argued that the provision of housing should be considered an integral component of the right to life. Thus, eviction, being violative of the basic necessity of housing, results in the violation of the right to life. ${ }^{71}$ This has provided a ground for indirect enforcement of forced eviction through public interest litigations under Article 102(1) of the Constitution. ${ }^{72}$

Second, the Constitution empowers the High Court Division to issue an order on the application of "any person aggrieved" in the absence of an equally efficacious remedy. ${ }^{73}$ By employing a liberal analysis, the Supreme Court has extended the concept of "aggrieved persons" to include individuals or groups other than the actual victim. Thus, any person or association who has a genuine cause or interest can come before the court when a public wrong violates the enjoyment of the fundamental right of an indefinite number of people. ${ }^{74}$ Such an expansion of the ground to litigate has provided the willing organizations with the

69. Constitution of the People's Republic of Bangladesh, Preamble.

70. Ibid., Arts $31,32$.

71. "The right to life which is guaranteed under the Constitution includes the right to livelihood and, since they will be deprived of their livelihood if they are evicted from their slum and pavement dwellings, their eviction is tantamount to deprivation of their life and is, hence, unconstitutional": Bangladesh Legal Aid and Services Trust and Others v. Government of the People's Republic of Bangladesh and Others [2008], p. 751.

72. Constitution of the People's Republic of Bangladesh, Art. 102(1) states that "[t]he High Court Division may, on the application of any person aggrieved, give such directions or orders to any person or authority, including any person performing any function in connection with the affairs of the republic, as may be appropriate for the enforcement of any of the fundamental rights conferred by Part III of the Constitution."

73. Ibid., Art. 102(1).

74. Dr Mohiuddin Farooque v. Bangladesh and Others [1997], p. 51. 
leverage to file a petition against forced eviction on behalf of the slum dwellers who would otherwise be barred from coming before the court, as a result of either being ignorant of their rights or living on the periphery of power dynamics.

Third, the evolution and increase of the scope of PILs, from the traditional civil and political rights to the socioeconomic rights such as, in particular, the right to environment, or other basic necessities like education, medical care, or food, ${ }^{75}$ alongside the accommodating attitude of the judiciary, have had a snowball effect on the emergence and growth of PILs challenging forced slum evictions in Bangladesh.

\subsection{Remedies for Forced Slum Evictions: Approach of the Bangladesh Supreme Court}

From a list of these cases, it can be discerned that the most litigated issue, with respect to violations of the housing provision, concerns the state-induced forced demolitions of urban slums. These cases are not focused on the individual, but rather form part of a strategic litigation to protect the collective interest of the slum dwellers by putting an end to the continuous practice of forced evictions. The first of these initiatives emerged in 1989 with the filing of a writ petition by the Ain o Salish Kendra, a local human rights organization, against the government for arbitrarily demolishing the Taltola Sweeper Colony of Dhaka. Although the court ruled in favour of the evicted slum dwellers, it awarded only a stay order or interim injunction. ${ }^{76}$

Almost ten years later in 1999, following a series of slum demolitions in Dhaka, several local human rights and non-governmental organizations filed the oft-cited Slum Dweller's case. The case produced two significant outcomes. First, the court recognized that the protection of slum dwellers from forced evictions is integral to their right to life and livelihood. Second, for the first time, the court affirmed the right to alternative accommodation of the slum people before evictions. In its remedial order, the court came up with detailed guideline for lawful eviction, as follows:

There should be a survey of all the families residing in any particular slum. There should be master plan or rehabilitation scheme or pilot projects to rehabilitate the slum dwellers. The slum dwellers should be given option either to go and live at their respective rural villages or to stay in an urban area. ... slum dwellers who do not opt for going to the rural home ... should be given a choice either to live in the slum or to elsewhere to live on therein. In case of their choice to stay in slums, they should be rehabilitated $\ldots{ }^{77}$

Later, in the Kalam case, the High Court Division liberally interpreted the principle of nondiscrimination and equality as the highest standard for directing the state's commitment to social justice, fairness, and dignity and to ensuring the enjoyment of constitutional rights by all people. The court, however, did not give any guideline as to how this standard should be satisfied, but rather took into account the government's promise to rehabilitate the evicted slum dwellers. ${ }^{78}$

75. See e.g. Dr Mohiuddin Farooque v. Bangladesh [2003]; BLAST v. Bangladesh [2005]; Human Rights and Peace for Bangladesh v. Bangladesh [2009]; Ain o Salish Kendra and Another v. Bangladesh [2011].

76. Hossain, supra note 4.

77. Ain o Salish Kendra (ASK) and Others v. Government of Bangladesh and Others [1999], p. 496.

78. Kalam and Others v. Bangladesh and Others [2001]. 
In an incidental case, a human rights organization anticipated the state-led demolitions of the Gudaraghat/Vashantek slum of Dhaka for the purpose of implementing several housing projects and filed a writ petition on behalf of 127 slum families who had been living there for almost 20 years. At first, the High Court Division issued a rule nisi against the government to show cause as to why the threatened eviction without maintaining the due process of law should not be declared invalid, being violative of the slum dwellers' constitutional right to life.

In the final judgment, by referring to the Indian case, Olga Tellis, ${ }^{79}$ the court observed that the fundamental principles of state policies, despite their non-justiciability, are equally important as fundamental rights in the governance of the country. Collectively, they determine the state's obligation, whether affirmative or negative. The government has a positive obligation to protect the fundamental right to life and livelihood of its people. The fundamental principle of the basic necessity of housing is integral to the right to life and livelihood, and hence is judicially enforceable. This remains even truer for the homeless and helpless slum dwellers, most of whom have migrated to cities for a better life and who, having nowhere to go, have ended up living a life of extreme deprivation in slums. Due to economic constraints and resource scarcity, of course, the state is not in a situation to provide housing for all people, or at least to the slum-dwelling populations. However, in accordance with its negative obligation, the state must ensure that no one is deprived of his right to livelihood and life without the due process of law. If eviction becomes necessary, there should be a prior master plan or pilot projects for rehabilitation, keeping in mind the best interest of those who dwell in slums. ${ }^{80}$ The court then held that the government must postpone its eviction plan until appropriate measures were put in place to undertake and finish the rehabilitation scheme for the slum dwellers within two years of the judgment.

The views of the court, as mentioned in the above cases, were also reaffirmed on procedural grounds in the subsequently litigated actions. For example, in the Aleya Begum case ${ }^{81}$ the court observed that no one should be evicted against his or her free will. In the Modhumala case, ${ }^{82}$ the court held that a service of notice within a reasonable time must be antecedent to the eviction of slum dwellers.

Now, the question is: to what extent have these judicial decisions been implemented to change the situations of the evicted slum dwellers or to prevent forced slum evictions? It is reported that, even though the slum dwellers succeeded in the Taltola Sweeper Colony case, between 1989 and 1998, more than 20 slums were demolished, leaving over 1 million slum settlers homeless. ${ }^{83}$ In violation of the detailed guidelines on slum eviction, several hostile evictions were attempted by the government. Ironically, in some cases, the displaced slum settlers again were forcibly evicted despite having stay orders from the court. ${ }^{84}$ A spate of eviction attempts in disregard of the court's orders has been a very frequent occurrence, even when the slum in question was the subject of a case awaiting final judgment. An example can be found in the case of the Korail slum eviction in which a stay order was sought in order to

\footnotetext{
79. Olga Tellis and Others v. Bombay Municipal Corporation [1985].

80. BLAST and Others v. Government of Bangladesh [2008], para. 14.

81. Aleya Begum v. Bangladesh and Others [2001], para. 37.

82. Modhumala v. Bangladesh [2001], paras 8-15.

83. COHRE \& ACHR, supra note 47, pp. 14-15.

84. Ibid., p. 14.
} 
maintain the status quo of the respective slum dwellers. On 4 April 2012, while a decision on the writ petition against the eviction was pending, a sudden eviction at the slum was pursued. It was one of the largest evictions to take place, occurred in the absence of measures for rehabilitation, and left approximately 2,000 slum families homeless. ${ }^{85}$

These instances of state-initiated forced slum evictions continue, despite the repeated and clear directives of the Supreme Court on eviction and resettlement. Although petitions challenging the forcible removal of several slums remain pending at the time of writing, the government has yet to make a comprehensive and sustainable master plan for rehabilitation of the affected slum dwellers. Rehabilitation projects, such as the Gharey Phera ("Back to Home Programme"), Asrayan ("Village Shelter Programme"), and Aadarsha Gram ("Ideal Village Project") have been grossly insufficient for bringing about any tangible benefit to the evicted slum dwellers. ${ }^{86}$

All these instances reveal that, despite the precedent set by the highest judiciary in Bangladesh, slum dwellers have been evicted in a wanton manner and continue to live under the constant threat of eviction. Ongoing disregard of the court directives by the government clearly indicates a culture of active state resistance to judicial authority, as well as a repudiation of the state's own obligation to protect the life and livelihood of the slum dwellers. Although PILs on forced slum evictions has contributed positively to mobilizing legal action and providing access to justice for the victims, the impact of judicial remedies has been minimal in terms of bringing about any meaningful behavioural change on the part of the government agencies. Consequently, the evictees may have attained a victory at the court, but their successes have failed to translate into reality outside the court premise.

Since the success of social rights adjudication depends vitally on the implementation of court orders, ${ }^{87}$ the above instances of tardy implementation hence prove that still there is a long way to go. The preceding analysis reveals that the court has either avoided ordering any remedy, has opted for a stay order due to the government's promise to implement a rehabilitation scheme, or has issued weak remedies, such as a recommendation or a declaratory order. These remedies are not robust enough to ensure implementation of and compliance with court orders.

Although almost three decades have passed since the filing of the first PIL on slum eviction, these judicial decisions have influenced the policy-makers only to the limited extent that they have modified their policies or have stopped government agencies from taking retrogressive measures. Meanwhile, the plight of the helpless evictees lacks redress and, being homeless, they are forced to live in deplorable conditions.

\section{REVIEW OF THE STRUCTURAL INJUNCTION: CHALLENGES AND SCOPE OF THE BANGLADESH SUPREME COURT}

\subsection{Pros and Cons of the Structural Injunction}

Judicial remedies in the context of socioeconomic rights litigations may range from affirmation of rights or identification of violations to complex policy-making through active

85. Shiree and Dustha Shasthya Kendra (2012).

86. Pereira, supra note 5, p. 72.

87. Gloppen, supra note 9 . 
judicial engagement. Hence, courts' remedial approach is either weak or strong. Where it is weak, a court may adopt a declaratory order stating that laws or actions are in breach of a social right obligation, thereby leaving it to the state to devise a remedy requiring specific actions to be taken. A court's approach may be strong in cases where the government is ordered to stop the illegal activities, or where the structural injunction is ordered, through which the judiciary retains a supervisory role over the implementation of its order. ${ }^{88}$ Also, in some cases, courts adopt modest and conversational remedial approaches, such as the "meaningful engagement remedy." 89

Indeed, courts' remedial decisions are very much context-specific. As the South African Constitutional Court in the Foses case noted:

Depending on the circumstances of each particular case the relief may be a declaration of rights, an interdict, a mandamus or such other relief as may be required to ensure that the rights enshrined in the Constitution are protected and enforced. ${ }^{90}$

Supporting the context specificity, scholars and judicial practices throughout the world have been singling out the structural injunction as an effective remedy in social rights adjudication in contrast to traditional remedies like declaratory or mandatory orders. ${ }^{91}$ But what is implied in the structural injunction that has led to this trend? The following discussion analyzes the answer from both theoretical perpestives and practical contexts.

In its most simplistic meaning, the "structural injunction enables a court to dictate how, when and in what ways a state must change its behavior to provide for the protection of people's rights." ${ }^{92}$ Hence, it is a reformative remedy. The root of this remedy lies in the systematic violation of human rights, in general. Socioeconomic rights violations may largely occur due to malafide institutional practice or discriminatory state policies. Redressing this situation, therefore, requires a structrual change to these faulty institutional and policy set-ups. PILs on systematic social rights violations require the active engagement of the judges in their administration and implementation, in addition to the legal issues. ${ }^{93}$ Hence, by ordering the structural injunction, judges aim to restructure existing bureaucratic deficiency to the extent it is threatening to the constitutional and public values. ${ }^{94}$ In sum, it requires "the violator to rectify the alleged breach under the court's supervision." 95 Its ongoing nature is facilitated by the court's retention of jurisdiction over the implementation of its order to ensure the state's compliance. Critics, however, point out several arguments against the use of the structural injunction in social rights litigation. In brief, the most cited among them are, first, that the court's supervision over governmental plans may lead to prohibitive enforcement costs and huge resource diversion. ${ }^{96}$ As such a remedy requires

88. Sunstein (2000-01); Tushnet (2004); Landau (2012).

89. Occupiers of 51 Olivia Road and Others v. City of Johannesburg and Others [2008]; Sailing Queen Investments v. The Occupiers La Colleen Court [2008]; Blue Moonlight Properties v. The Occupiers of Saratoga Avenue and Others [2009]; Chenwi (2009).

90. Fose v. Minister of Safety and Security [1997] 7 BCLR 851 (CC), para. 19.

91. Hirsch (2007), p. 1; Roach \& Budlender (2005); Landau, supra note 88.

92. Hirsch (2007), p. 18.

93. Chayes (1976), p. 1284.

94. Fiss (1979), p. 1.

95. Currie \& Wall (2005), p. 217.

96. Ebadolahi (2008), p. 1597. 
continued judicial involvement; it represents an ambitious undertaking for a judiciary whose resources are constrained.

Second, implementation of this remedy violates separation of powers among the state organs by creating space for judicial usurpation of legislative or executive activities. ${ }^{97}$ In the Eldridge case, the Canadian Supreme Court preferred a declaratory remedy to the injunctive relief, as the former abrogates the judge's scope to dictate on the legitimate political functions. ${ }^{98}$ Therefore, in the Treatment Action Campaign case, the South African Constitutional Court observed:

Courts are ill-suited to adjudicate upon issues where Court orders could have multiple social and economic consequences for the community. The Constitution contemplates rather a restrained and focused role for the Courts, namely, to require the State to take measures to meet its constitutional obligations and to subject the reasonableness of these measures to evaluation. Such determinations of reasonableness may in fact have budgetary implications, but are not in themselves directed at rearranging budgets. In this way, the judicial, legislative and executive functions achieve appropriate constitutional balance. ${ }^{99}$

Third, this remedy demands that judges must diligently employ legal, political, as well as analytical skills. In practice, however, judges are often institutionally ill-equipped to adopt the remedy on such terms. ${ }^{100}$ Fourth, the state actors responsible for implementing a plan under the structural injunction may remain reluctant to have the plan approved by the court or may fail to submit the plan to the court in due course. ${ }^{101}$ And, lastly, the the structural injunction is a time-consuming remedy, as it engages the judge in a full-time supervisory role. ${ }^{102}$ In effect, it hinders the capacity of the court to deal with other pending litigations.

The following arguments, however, counter these objections to the adoption of the structural injunction. First the structural injunction denotes a response to the inadequacy of conventional judicial remedies. Since the systematic state-induced violations of social rights are too "defused or nebulous, damages, for example, as a one-shot remedy may not be able to repair the harm." ${ }^{103}$ Traditional remedies are premised on a monologic process requiring no conversation between the judiciary and policy-makers. Judges grant weak or deferential remedies like a declaratory relief or a recommendation usually on the basis that the defaulting state organ will comply with the court order. By contrast, strong or intrusive remedies like mandatory, prohibitive, or negative orders assert courts' intention to decide the case once and for all. But what would happen if the government were to remain irresponsive to courts' orders? The most effective solution, in this case, is the adoption of a remedy that aims to identify and tackle the root of the problem through dialogue with the government. ${ }^{104}$ Being a continuous remedy, the structural injunction facilitates this possibility, as it is based on the principle that implementation of judicial orders must be accompanied by political compliance. As the

\footnotetext{
97. Frug (1978), pp. 735-6.

98. Elridge v. British Columbia [1997].

99. Minister of Health v. Treatment Action Campaign [2002], paras 37-38.

100. Landau, supra note 88, pp. 235-6.

101. Ngxuza and Others v. Permanent Secretary, Department of Welfare, Eastern Cape and Another [2001]; Ebadolahi, supra note 96, p. 1597.

102. Landau, supra note 88, p. 236.

103. Hirsch, supra note 91, p. 22.

104. Pieterse (2004), p. 414.
} 
structural injunction does not dictate the details of state policies and rather engages with the government in the formulation and implementation of policies, it potentially reduces the chance of reluctance and thus becomes capable of tackling the systematic harm.

Second, it would be erroneous to say that the structural injunction transgresses the separation of powers among the governmental organs. In the Swann case, while granting the structural order, the US Supreme Court rightly asserted that "[r]emedial judicial authority does not put the judges automatically into the shoes of the school authorities whose powers are plenary. Judicial authority enters only when local authority defaults." ${ }^{105}$ The legitimate basis for interfering with the political functions emanates from the misconduct, demonstrated unwillingness, or incapacity of policy-makers to perform the state's obligations, whether affirmative or negative. By ensuring more co-operation from the executive or legislature and by balancing conflict, this remedy offers a more effective solution. ${ }^{106}$ Perhaps its greatest benefit is not that it enables courts to act, but rather that its breadth prevents policy-makers from retrogressive acts and ensures accountability. It is, therefore, rightly observed that structural interdicts:

have contributed to a better understanding on the part of public authorities of their constitutional legal obligations in particular cases, whilst it has also assisted the judiciary in gaining a valuable insight in the difficulties that these authorities encounter in their efforts to comply with their duties. ${ }^{107}$

Third, the structural injunction is not a time-consuming remedy. Rather, it manages the delay that is needed to implement a court order. Conventional remedies opt for immediate redress of the violation. In systematic harm, however, where the delay is inevitable, the long-term remedy is the most appropriate. ${ }^{108}$ For example, in the Brown case, the US Supreme Court acknowledged the potential delay due to complex administrative and bureaucratic processes. The court then allowed itself the additional time needed for carrying out the ruling. ${ }^{109}$ Indeed, the inclusion of a time limit, within which the required standard for government action must be realized, and implementation of the court's monitoring role together ensure the progressive realization of rights and inhibit systematic violation.

Fourth, social rights litigation is largely about pro-poor litigation by targeting eradication of deprivation and inequality. In contrast to the individualized enforcement, negative injunction, or weak remedies, the structural injunction, when it is claimed and issued, achieves this purpose effectively. ${ }^{110}$ It is directed at implementing the judicial order as a precondition for successful social rights adjudication. At the operational level, being a systematic relief as opposed to an immediate relief, it vitally benefits the lower-income groups in three ways: first, by assisting them in the costly follow-up of the implementation stage $^{111}$; second, by making provision for a collective remedy to ensure distributive justice $^{112}$; and, last, by altering adverse governmental practices and procedures in order to

105. Swann v. Charlotte-Mecklenburg Board of Education [1971] 402 US 1, 16 (Swann).

106. Hirsch, supra note 91, pp. 58-60.

107. Magidimisi v. Premier of the Eastern Cape and Others [2006] ZAECHC 20 (High Court), para. 29.

108. Roach, supra note 7, p. 111.

109. Brown v. Board of Education [1955] 349 US 294 (Brown).

110. Landau, supra note 88, p. 413.

111. Swart (2005), p. 228; Ebadolahi, supra note 96, p. 1592.

112. Mbazira (2009), pp. 195-6. 
prevent recurrence of violations. ${ }^{113}$ Now, if any court wants to adopt the structural injunction, should it order the remedy regularly or only in exceptional circumstances?

The remedial choice of the judiciary largely depends on the nature of the political context. Weak remedies work well in a rights-responsive system. An interpretation of judicial remedies from "Constitutional Dialogue" theory suggests that courts should either adopt a weak rights-strong remedies approach to adjudicate the negative dimension of social rights and strong rights-weak remedies approach to the positive dimension. When a right is weakly protected under the constitutional or legislative scheme, and the state remains overly insensitive to its duty to protect it, a weak remedy may contribute to making the right weaker. ${ }^{114}$

Even an incrementalist like King, who argues for judicial avoidance in social rights litigation, acknowledges the need for the structural injunction, albeit advocating its occasional use. According to King, courts should opt for non-intrusive or weak remedies in circumstances where favourable political conditions prevail, as expressed through the presence of an independent and non-partisan judiciary, a democratic polity with a sincere and serious commitment to basic rights, and a competent and non-corrupt bureaucracy. When, on the other hand, an alternative remedy, such as administrative remedy, is available, courts should choose non-intrusive or weak remedies. When, however, these are absent, and when the state chronically and patently ignores its constitutional and legal obligations, the structural injunction is the last-resort remedy. ${ }^{115}$

In discussing the use of the structural injunction in South Africa and Canada, Roach and Budlender argue that:

declarations and requirements that governments report to the public will often be sufficient in those cases where governments are merely inattentive to rights, stronger remedies involving mandatory relief and requirements of governmental reporting to the courts may be necessary in some cases, and particularly where governments are incompetent or intransigent with respect to the implementation of rights. ${ }^{116}$

How can a court overcome its resource constraints and influence political compliance in the follow-up process? The structural injunction is a conversational remedy intended to foster dialogue between policy-makers and the judiciary. However, for the judiciary to employ the structural injunction successfully, it would be preferable for it to opt for multifaceted organizational collaboration. This can be done by engaging the key stakeholders in the litigation process, such as the judicial commission, human rights commission, ombudsman, human rights organizations, civil society groups, etc. An example can be sought from Abuja, Nigeria, where a National Advisory Board has been established to start a co-operative dialogue with the government on access to land, secure land tenure, and affordable housing. The board consists of representatives of the government, private sector, media, judiciary, traditional and religious communities, as well as international specialists. ${ }^{117}$ While this is not an example of the structural injunction per se, it denotes how the judiciary and the executive

\footnotetext{
113. Hirsch, supra note 91, p. 19.

114. Dixon (2007), p. 391.

115. King (2012), pp. 275, 286; Ahmed \& Khaitan (2015), pp. 607, 609, 623-5.

116. Roach \& Budlender, supra note 91, p. 327.

117. Eerd \& Banerjee (2013), p. 21.
} 
can collaborate to achieve housing policy objectives. In this regard, on the capacity of the Indian judiciary, the Supreme Court of India observed: "[t]he Court is entitled to, and often does, seek the assistance of expert panels, Commissioner, Advisory Committees, Amici, etc."118

\subsection{Use of the Structural Injunction by National Courts}

Due to the inherent potential of the structural injunction, numerous national courts over the years have successfully adopted this remedy in rights litigation. ${ }^{119}$ This tendency suggests that the need for this remedy is justified and that the Bangladesh Supreme Court also can legitimately exercise its supervisory jurisdiction. The following discussion examines a few examples from US, Canadian, Indian, South African, and Colombian courts.

The commonly cited school desegregation case, Brown II is the first case where the US Supreme Court insisted on exercising judicial supervision over the implementation of its order. ${ }^{120}$ In accordance with its idealized vision of reforming public institutions and protecting disadvantaged groups, the court in a subsequent case observed that "[o]nce a right and a violation have been shown, the scope of a district court's equitable powers to remedy past wrongs is broad." 121 Over the years, the court successfully ordered this remedy in numerous social rights cases ranging from prison reform to employment discrimination. ${ }^{122}$ This remedy emerged and continued to develop as a response to the failure of traditional remedies in effectuating constitutional compliance. ${ }^{123}$

The Canadian trial courts during the 1980s attempted to issue the structural interdict in some social rights cases, mainly those on minority language. ${ }^{124}$ Later, in 2003, the Canadian Supreme Court observed that the trial judge could, after ordering the government to provide for minority-language schools, issue the structural injunction to enable it to supervise the government's compliance via receipt of regular progress reports. ${ }^{125}$

\footnotetext{
118. Sheela Barse v. Union of India and Others [1988], para. 6 (Sheela Barse).

119. For example, in the TAC case, the court issued a structural order alongside a mandatory order to provide medical care to the applicant, Treatment Action Campaign v. Minister of Health [2002]; the Canadian Supreme Court by a majority decision affirmed the trial judge's order to retain supervision in a minority-language case, Doucet-Boudreau v. Nova Scotia (Minister of Education) [2003]; In the Mendoza case, the Supreme Court of Argentina ordered the government and local authorities to present a plan to protect the La Matanza-Riachuelo river basin from environmental hazards. The court conducted a series of public hearings to monitor the progress of the compliance, Mendoza, Beatriz et al. v. the Argentine Government et al. for harms, M.1569.XL [2008].
}

120. Brown, supra note 109.

121. Swann, supra note 105.

122. For example, Feeley \& Swearingen (2004), pp. 433-4 in the context of the US prison condition cases state that the exercise of judicial supervision catalyzed the prison reform. They stipulate that "[o]ver the past thirty years, litigation has had a dramatic impact on nation's jails and prisons ... old patterns have reappeared as soon as courts have turned their attention elsewhere or terminated jurisdiction." See also Reynolds v. Sims [1964]; Pasadena City Board of Education v. Spangler [1976]; Hutto v. Finney [1978]; Bell v. Wolfish [1979].

123. Gillespie (1989-90), p. 198 states that "[i]t is the degree of failure and resistance and resistance to the declarations which ultimately necessities the injunctive decrees as the judiciary is gradually put in the position of being left with no remedial option but to interfere more and more specifically .... The practical reality is that if the traditional declaration and less intrusive orders do not work then the court ultimately has to choose to retreat from its position on the constitutionality of the underlying right, allow the breach to go un-remedied, or specify how the institution can comply; the latter potentially and gradually becomes a structural injunction."

124. Marchand v. Simcoe Country Board of Education [1986]; Lavoie v. Nova Scotia [1988].

125. Doucet-Boudreau v. Nova Scotia (Minister of Education) [2003]. 
From 1997 onwards, the Colombian Constitutional Court has issued the structural injunction in a number of cases with varying levels of success. Among these, the most cited is the Displaced Persons case of 2004. In that case, a constitutional complaint ("Tutela") was filed against the state for its failure to provide emergency relief and the basic necessities like food, shelter, housing, health, and education to the Internally Displaced Persons (IDPs). Following its order to rectify the alleged violation, the court retained its supervisory authority over the case. According to the court:

the State's response has serious deficiencies in regards to its institutional capacity, which cross-cut all of the levels and components of the policy, and therefore prevents, in a systematic manner, the comprehensive protection of the rights of the displaced population. The tutela judge cannot solve each one of these problems, which corresponds to both the National Government and territorial entities, and to Congress, within their respective margins of jurisdiction. Nevertheless, the above does not prevent the Court, in verifying the existence of a situation of violation of fundamental rights in concrete cases, from adopting corrections aimed at ensuring the effective enjoyment of the rights of displaced persons, as it will do in this judgement, nor from identifying remedies to overcome these structural flaws, which involve several State entities and organs. ${ }^{126}$

An empirical study on the aftermath of this case reveals that the decision influenced the government to draft a co-ordinated national policy on the IDPs, allocating an increase of budgets to ensure the enjoyment of the minimum content of their basic necessities. The case also resulted in increased collaboration among the related agencies. Although not all the basic necessities were improved at the same rate, the situation of the IDPs, at least regarding their enjoyment of health and education, was materially and substantially changed. ${ }^{127}$

The Indian Supreme Court also embraced a similar approach. On the need for the structural injunction, a judge of the Indian Supreme Court once contended that, in social rights litigation,

the court is not merely a passive, disinterested umpire or onlooker, but has a more dynamic and positive role with the responsibility for the organization of the proceedings, moulding of the relief and this is important also supervising the implementation thereof. ${ }^{128}$

This attitude was adequately reflected in the popularly known Right to Food case. In this case, a writ petition was filed against the federal government for its unfair food distribution policy. It was alleged that the government was storing rather than distributing a huge amount of grains even when the people were suffering in chronic famine. In addition to its initial declaratory order, the court issued several interim orders relating to the creation of special programmes for delivering food to poor families, implementing a complex food-to-work campaign and creating a school lunch programme for children. Notably, the court retained supervisory jurisdiction over the case. In doing so, it appointed a judicial commission consisting of two members to monitor the implementation by collecting information and mediating on policy changes with the state. ${ }^{129}$ The case resulted in the successful implementation of the "Mid-Day Meal Scheme" (MDMS) in several provinces. ${ }^{130}$

126. T-025 [2004], paras 6, 3, 1, 4 .

127. Garavito (2011).

128. Sheela Barse, supra note 118 , para. 6.

129. People's Union of Civil Liberties v. Union of India [2007] 12 SCC 135 (PUCL).

130. Khera (2006), p. 4743 commented that following the Supreme Court orders "the government of India revised its guidelines for the MDMS in 2004. According to these guidelines, the MDMS was being fully implemented in 20 states 
Looking to South Africa, which is the pioneer of social rights litigation, it is found that, initially, the South African Constitutional Court had a strict reservation to order the structural remedy in social rights cases. ${ }^{131}$ By contrast, the High Court in some cases adopted this remedy, although those decisions were later reversed by the Constitutional Court. However, due to gross non-implementation of those judgments, it appeared doubtful whether weak remedies could bring any difference in the lives of the impoverished litigants. ${ }^{132}$ The declaratory orders of the Grootboom or the Treatment Action Campaign cases, for instance, failed to improve the litigants' condition on the ground. Consequently, in recent years, there has been a shift in the Constitutional Court's remedial choice toward the adoption of structural injunction through some progressive judgments.

Among multiple numbers of eviction cases, Occupiers of 51 Olivia Road was the first case where the Constitutional Court ordered the structural injunction, albeit merely an interim structural injunction. ${ }^{133}$ The court's order required the parties to

engage with each other meaningfully ... in an effort to resolve the difference and difficulties aired in [the application] in light of the values of the Constitution, the constitutional and statutory duties of the municipality and the rights and duties of the citizens concerned. ${ }^{134}$

The Constitutional Court manifestly ordered the structural injunction in two eviction cases, popularly cited as Pheko ${ }^{135}$ and Schubart Park. ${ }^{136}$ In Pheko, the municipality was alleged to have evicted the litigants forcefully without providing any alternative accommodation. The Constitutional Court ordered both the parties to engage in discussion to reach an equitable solution. However, following the municipality's repeated non-compliance with this order, the court in the contempt proceeding finally adopted the structural injunction. This case provides a good illustration of the authority of the court to retain supervisory jurisdiction at the implementation stage and of the circumstances under which adoption of such remedy is appropriate. The court observed as follows:

disobedience towards Court orders or decisions risks rendering our courts impotent and judicial authority a mere mockery ... . Courts have the power to ensure that their decisions or orders are complied with by all and sundry, including organs of state. ... this Court should exercise its supervisory jurisdiction to enable the respondent to report to the Court about whether land has been identified and designated to develop housing for the applicants. ${ }^{137}$

(F'note continued)

and all seven union territories, and partially in the remaining eight states. Since then, the coverage of MDMS has been further extended, and today it is close to universal"; for further evaluation of the success of the court orders, see also Young (2012), pp. 204-6; Birchfield \& Corsi (2010).

131. Until the decision of the 51 Occupiers of Olivia Road case, the South African Constitutional Court issued structural injunction only twice in the cases that involved civil and political rights. The first one was on the prisoners' right to vote and the second case dealt with the substitution of lawful punishment for prisoners in death row. See August and Another v. Electoral Commission and Other [1999]; and Sibiya and Others v. Director of Public Prosecution Johannesburg and Others [2005].

132. Mbazira (2008).

133. Chenwi (2008).

134. Occupiers of 51 Olivia Road and Others, supra note 81, para. 5.

135. Pheko, supra note 63.

136. Schubart Park Residents Association and Others v. City of Tshwane Metropolitan Municipality and Others [2013].

137. Pheko, supra note 63, paras 1-3. 
The structural injunction was ordered in Schubart Park for similar reasons. In both the cases, however, this was not issued as an independent remedy, but rather was coupled with the declaratory orders.

Although the Constitutional Court is experimenting with the use of the structural injunction as a remedial strategy, nevertheless, the above decisions are helpful for indicating the changed attitude of the South African judiciary. These cases also demonstrate that judicial supervision is an effective way of creating a dialogue with concerned state agencies and related stakeholders with a view to achieving a meaningful outcome, particularly when economic insecurity and resource constraints exist. ${ }^{138}$

\subsection{Scope of the Bangladesh Supreme Court to Adopt the Structural Injunction: Overcoming the Challenges}

The circumstances of developing countries present some unique challenges that may vitally influence the remedial decisions of courts in general, and particularly impact upon the adoption of the supervisory remedy. In the face of systematic violation of socioeconomic rights, these challenges include poverty, as well as poor governance, legislative and executive inertia, inadequate implementation of the separation of powers, lack of judicial independence, enforcement costs, or judicial unwillingness to be creative by crossing courts' traditional limit. ${ }^{139}$ As Khan points out, PIL challenges in Bangladesh have increasingly been framed as actions brought to protect fundamental rights, in an effort to ensure government accountability, including in the case of slum evictions. ${ }^{140}$ However, as the Supreme Court's decision in the Slum Dwellers case demonstrated, the court had found it difficult to resist political pressure from the executive to allow the government's actions to proceed unhindered by court order. ${ }^{141}$ Hence, she suggests that support for plaintiffs from the political opposition, media, and international community in cases of social rights violations would assist in addressing the problem of the judiciary reluctant to impose stronger remedies such as the structural injunction on government authorities. ${ }^{142}$

There are two key challenges that have prevented the Bangladesh Supreme Court from adopting the structural injunction in litigation concerning forced slum evictions. While the first relates to doubts as to the constitutional authority of the judges, the second is about concerns as to their institutional capacity. Confusion as to the constitutional authority stems from the weak constitutional content of the basic necessity of housing, which, being a directive principle, is subject to progressive realization and resource constraints. Hence, the judges doubt their legitimacy to order the structural injunction so as to remedy the violation of this provision. ${ }^{143}$

138. Pillay \& Wesson (2014), p. 335.

139. This list of challenges to judicial remedies, in general and structural injunction, in particular, has been developed from the researchers' understanding as developed from numerous readings, Khosla, supra note 62; Landau, supra note 88 .

140. Khan (2012), p. 265.

141. In the context of a forced slum eviction case of Bangladesh, Ain o Salish Kendra v. Bangladesh [1999], it is found that the High Court Division allowed the government's eviction attempt and ordered only a declaratory remedy directing the government to provide alternative accommodation to the evictees. This was because the active political resistance compelled the court to back down and leave the remedy in the hands of the executive. See ibid., pp. 266-9.

142. Ibid., p. 269.

143. Realization of rights that impose deferred state obligations embraces weak remedial orders by leaving the government flexible space to take steps as per its socioeconomic condition. Hence the Canadian Supreme Court in a 
Moreover, the conservative perspective on the constitutional separation of powers bars the judiciary from supervising the actions of policy-makers. This confusion time to time is expressed through a restrained understanding about the nature of fundamental principles and corresponding obligations to realize social rights. ${ }^{144}$

However, the basic necessities, as directive principles, inform the spirit of the Constitution. Therefore, despite these being judicially non-enforceable, the Constitution does not discharge the state from realizing its constitutional commitment to create an equal and just society by eradicating all forms of exploitation and discrimination. ${ }^{145}$ Due to complexity in identifying states' duty for the realization of socioeconomic rights, in the international human rights discourse, in recent years, there has been a normative shift from the "obligations approach" to the "violations approach." 146 While the former insists on the positive state obligations the realization of which is subject to progressive realization and resource availability, the latter emphasizes on the negative obligation to enforce social rights whenever there occurs a violation.

The "violations approach" considers three categories of violations. These are, first, violations caused by domestic laws or policies; second, violations resulting from discriminatory measures and practices; and, third, violations due to the failure to perform the minimum core obligations. ${ }^{147}$ Protection of the right to housing from these violations does not have economic implications, but rather imposes an immediate duty upon states, the violation of which calls for judicial protection. As a result, although it may not be possible for a poor country to ensure housing for all, the government cannot derogate from its obligation to stop forced slum evictions. ${ }^{148}$

The Supreme Court of Bangladesh also seemed to take into account this development in perspective. In one case, the court observed that:

the slum dwellers, poorest of the poor they may be, without any future or dreams for tomorrow, whose every day ends with a saga of struggle with a bleak hope for survival tomorrow, but they are also citizens of this country, theoretically at least, with equal rights.

(F'note continued)

case for providing interpretive services to the deaf hospital patients, Eldrige v. British Colombia [1997] observed that: "[a] declaration as opposed to some kind of injunctive relief is the appropriate remedy in this case, because there are myriad options available to the government that may rectify the unconstitutionality of the current system. It is not this Court's role to dictate how this is to be accomplished."

144. For example, while expressing judicial deference to the political executives in realizing the fundamental principles, Chief Justice Shahabuddin Ahmed observed that: "[The fundamental principles] are in the nature of people's programmes for socio-economic development of the country in peaceful manner, not overnight, but gradually. Implementation of these programmes requires resources, technical know-how and many other things including masseducation. Whether all these pre-requisites for a peaceful socio-economic revolution exist, is for the state to decide. If the state does not or cannot implement these principles, the Court cannot compel the state to do so." Kudrat-E-Elahi v. Bangladesh [1992], para. 22.

145. Haque (2005), p. 45.

146. Audrey R. Chapman for the first time introduced this approach as a mechanism to assess and monitor States Parties' compliance to realize the rights enumerated in the ICESCR. See Chapman (1996); see also Sepulveda (2003), pp. 20-2.

147. Chapman (1996), pp. 23-4; Scott Leckie also contends that obligations relating to "progressive realization rather should be the standard to guide the state to act against the repressive laws, policies and practices that bar the enjoyment and realization of Convent rights"; see Leckie (2003), p. 13.

148. "Regardless of the state of development of any country, there are certain steps which must be taken immediately. As recognized in the Global Strategy for Shelter and in other international analyses, many of the measures required to promote the right to housing would only require the abstention by the government from certain practices": GC No. 4, supra note 11, para. 10; see also GC No. 7, supra note 14, para. 8; International Commission of Jurists (2008), p. 27. 
Their fundamental right may not be fully honoured because of the limitations of the State but ... they have got a right to be treated fairly and with dignity, otherwise all the commitments made in the sacred Constitution of the People's Republic, shall prove to be a mere mockery. ${ }^{149}$

This approach, however, is only limited to the interpretation of the state's procedural duty on forced slum evictions and is yet to be reflected in the remedial order. As discussed earlier, the Supreme Court of Bangladesh has been greatly influenced by the "violations approach" as applied in the Indian Olga Tellis case. But the decision of the case is criticized for being extremely deferential and recognizing only the procedural rights of the evicted pavement dwellers instead of bringing about any tangible outcome. ${ }^{150}$ Indeed, the case is significant for locating the wrong done by the state. However, to effectively redress an alleged infringement, a reasoned extension of this approach to the remedial orders may direct the judiciary to innovate an effective remedy like the structural injunction. The PUCL case constitutes a good example where the Indian Supreme Court enforced the violation of the provision of food as a justiciable content of the right to life and successfully ordered several structural orders. Instead of following the remedial approach of Olga Tellis, the Bangladesh Supreme Court can apply the PUCL approach in forced slum evictions litigations, since the constitutional provisions on housing and food of both the countries impose similar state obligations.

Also, the constitutional scheme does not mandate a strict separation of powers. In reality, absolute separation of powers is neither possible nor desirable. The Constitution of Bangladesh, therefore, provides for checks and balances among the three organs of the state. The Supreme Court acts as the guardian of the Constitution and thus can review and strike down unconstitutional legislative and administrative actions. The dominance of constitutional supremacy over parliamentary supremacy explicitly mandates such a role of the court that can extend to its remedial authority. ${ }^{151}$ Particularly, to redress forced slum evictions, the judiciary can validly exercise its broad remedial authority and devise any remedy, however strong, if it is satisfied that the remedy will be efficacious within the constitutional scheme. This is because, first, as mentioned earlier, by liberal interpretation of Article 102(1) of the Constitution, the court has extended its remedial power to redress forced slum evictions as violations of the fundamental right to life. Second, the High Court Division, in exercise of its equitable authority, can issue necessary relief beyond the "equally efficacious remedy" to enforce the "principle of legality" under Article 102(2) of the Constitution. ${ }^{152}$ Third, the

149. BLAST v. Bangladesh [2008], para. 19.

150. Langford, supra note 5, p. 106.

151. Art. 7(2) of the Constitution of Bangladesh recognizes that, the Constitution being the supreme law of the country, any law that contradicts the Constitution shall be declared void as to the extent of the inconsistency; see also Art. 26 on the authority of the Supreme Court to declare "laws inconsistent with fundamental rights to be void" and Art. 102 on the powers of the High Court Division to enforce fundamental rights.

152. "The words 'no other equally efficacious remedy is provided by law' appearing in clause 2 of article 102 is very pertinent as well as important because that is the precondition for exercising the power of the High Court to issue the writ certiorari. ... If the High Court division is satisfied that the available remedy is efficacious but not equally efficacious, then in exercise of its discretion, depending on the facts and circumstances of the case in hand." Siddique Ahmed v. Government of Bangladesh and Others [2013] 65 DLR 8 (AD); "The High Court Division, may if satisfied that no other equally efficacious remedy is provided by law - (a) on the application of any person aggrieved, make an order - ... (ii) declaring that any act done or proceeding taken by a person performing functions in connection with the affairs of the Republic or of a local authority, has been done or taken without lawful authority and is of no legal effect": Bangladesh Constitution, Art. 102(2)(a)(ii). 
Appellate Division has wide remedial authority to issue any order at its discretion to do "complete justice" while securing the litigants' fundamental rights. ${ }^{153}$

The second challenge, relating to the institutional incapacity of the judiciary due to resource constraints, can also be overcome. Some might argue that it would be financially burdensome for the Bangladesh Supreme Court to order the structural injunction when it has to operate within a limited budget. Another concern suggesting the court's inadequate institutional capacity is the court's huge case-load. Faced with the enormous volume of cases, judges may find it ineffective to order the structural injunction, as this remedy requires constant judicial engagement.

Practically, however, resource constraint is not a challenge unique to this remedy. ${ }^{154}$ Remedies like declarations or recommendations as adopted by the Bangladesh Supreme Court in the forced slum eviction cases also involved economic implication, as they were not decided overnight. Besides, the structural order of the Indian Supreme Court in the Right to Food case demonstrates a practical example that even a resource-constrained court can employ the structural injunction. Since the Supreme Court of Bangladesh also adopted this remedy in some cases, as discussed later in this part, cost alone does not constitute a strong reason to deny the structural injunction to redress forced slum evictions.

Speedy disposal of cases is necessary to avoid any backlog. Where the systematic violation is the issue, the primary concern of the court is to ensure the systematic prevention of violations, which, as mentioned earlier, may require significant periods of time to implement. The structural injunction is not about the lone involvement of the court. Alongside judicial activism, full compliance with social rights judgments requires greater collaboration among the institutions of government and governance. ${ }^{155}$ This co-operation will help the court indirectly to minimize and share any burden, whether that is due to resource constraint or overwhelming case-load. As a result, numerous efforts have been made by national courts to employ a participatory remedial strategy at the follow-up stage. This has been done by appointing judicial commissioners, ${ }^{156}$ or by collaborating with the relevant stakeholders such as the Human Rights Commission, ${ }^{157}$ civil societies, and litigating organizations ${ }^{158}$ to strengthen courts' institutional capacity. The Bangladesh Supreme Court has sufficient scope to employ this participatory remedial strategy. For instance, the National Human Rights Commission of Bangladesh, under its governing legislation, is empowered to investigate and monitor the human rights situations of the country.

153. "The Appellate Division shall have power to issue such directions, orders, decrees, or writs as may be necessary for doing complete justice in any cause or matter pending before it," Bangladesh Constitution, Art. 104.

154. Hirsch supra note 91 , p. 56, states that "[a]ll orders, including declaratory orders can have profound financial and policy implications on the state; the fact alone cannot justify courts not ordering appropriate relief."

155. For example, by recognizing the potentials of involving Human Rights Commission, in the South African context, Ebadolahi, supra note 96, p. 1602, argues that "[t]he Commission's involvement in ESR rights cases where a structural interdict is issued can make this remedy more effective, ultimately enhancing judicial enforcement of socioeconomic rights in South Africa."

156. In the Right to Food case, the Supreme Court of India appointed two commissioners to provide report on the implementation process; see PUCL, supra note 129.

157. In the Grootboom case, the South African Constitutional Court ordered the South African Human Rights Commission to provide report on the progress of implementing the court order (see Government of the Republic of South Africa and Others v. Grootboom and Others [2000]).

158. In the displaced persons' case, the Colombian Constitutional Court, alongside its structural order, effectively co-ordinated with the civil society orgranizations to participate in monitoring the implementation process, Decision T-025/04 [2004] (Colombian Constitutional Court). For further analysis, see Garavito, supra note 127. 
Whenever needed, the Supreme Court can also require a report from the commission on any pending matters concerning the violation of fundamental rights. ${ }^{159}$

Lastly, one practical example furthers this discussion on the ability of the Bangladesh Supreme Court to adopt the structural injunction. This remedy is not alien to judges. The judiciary has successfully experimented with this remedy in some important civil and political rights cases. In the Separation of Judiciary case, the High Court Division issued a landmark judgment by ordering the government to separate the judiciary from the executive, so that the court's order could be implemented within two months. The decision was later reaffirmed by the Appellate Division. With the government evincing continued reluctance over a period of eight years, the judiciary continued to rely upon its monitoring authority. This strong judicial involvement resulted in the long overdue separation of the judiciary from the executive arm of government. ${ }^{160}$ Furthermore, in the well-known Prisoners case, a petition was filed challenging the illegal detention of foreigners in several jails. The court ordered the government to initiate necessary institutional reform. The designated persons from the jail authority, including the superintendent of the Central Jail and IG Prison, were ordered to submit a time-bound report on the release of those prisoners. ${ }^{161}$

At the same time, apart from pure civil and political rights cases, the court has appeared to extend this remedial authority to cases that are widely related to the development or the environment taking into consideration the fundamental principles of state policies. In 2009, in the popularly known Pure Food case ${ }^{162}$ concerned with preventing widespread food adulteration, the High Court Division directed the government to establish a food court and to appoint an adequate number of public food analysts in every district in accordance with the Pure Food Ordinance 1959. The government was ordered to implement this direction within one year from the judgment. The court also directed the government to report on its progress on a timely basis. In consequence to this ruling, the government has appointed a number of food analysts, although the food court is yet to be set up in every district apart from the metropolitan areas. ${ }^{163}$ In another case, two human rights organizations filed a writ petition challenging that excessive imposition of charges in the name of admission fees or compulsory donations by the private educational institutions of all levels (primary, secondary, and higher secondary) were inconsistent with the relevant laws and policies. They also challenged that the Ministry of Education, Ministry of Primary and Mass Education, Directorate of Primary Education and Higher Education, and all education boards had failed to act as per their constitutional and legal obligations by not investigating the allegations of fee increases, not taking steps against the wrongdoers, and not remedying the plights of the victims. The High Court Division issued a rule nisi as well as an interim order directing the ministry to take immediate steps for complying with their constitutional and statutory duties. The court also ordered the respondents to submit a report within three months on its progress

159. The National Human Rights Commission Act 2009 (Bangladesh), s. 13(1) states that "the Supreme Court may refer any matter arising out of an application made under article 102 of the Constitution, to the Commission for submitting report under inquiry."

160. Masdar Hossain v. Secretary, Ministry of Finance [1998]; Secretary, Ministry of Finance v. Masdar Hossain [2000].

161. Faustina Pereira v. State [2001].

162. Human Rights and Peace for Bangladesh v. Bangladesh [2009].

163. Sarker (2013). 
to implement the directives. Importantly, by affirming the rule and order, the court adopted a continuing mandamus upon the Ministry of Education (Respondent No. 1) to ensure that its policy regarding admission fees were being followed absolutely and that educational institutions could not cause any prejudice to the students' interests. ${ }^{164}$ Thus, if the court can order the structural injunction in a case concerning food or education, it can also do so in the cases of forced slum eviction. All these cases concern the basic necessities, and present similar challenges to the judiciary.

Arguably, to overcome the challenges above to the ordering of the structural injunction, there must be an increase in the judicial willingness to adopt this remedy, and this requires the presence of two factors. Since remedy selection depends on the role perception of the court, ${ }^{165}$ "a change in the judges' intellectual and functional perceptions of law, justice and their judicial authority" is needed in the first instance. In addition, in order to effectuate that role, judges need to cultivate the "application of judicial pragmatism and/or craftsmanship to engage with the government branches" in the litigation process. ${ }^{166}$

\section{CONCLUSION}

Conventional judicial remedies, such as declarations or recommendations, proceed on the assumption of good-faith compliance on the part of governments. Consequently, these remedies are inappropriate to bring about compliance where governments are either incompetent or unwilling to implement the judicial decrees. The structural injunction, by contrast, being a dialogic remedy, engages the relevant state agencies in a collaborative process to ascertain an amicable solution that is capable of enforcement. Continuous nonimplementation of court orders by governments, brought to light by the forced slum evictions litigation in Bangladesh, presents an appropriate circumstance for the application of this remedy. Given the court's capacity to overcome the challenges in adopting this remedy, hence, it is legitimate for the judges to retain supervision over the execution of the court's orders on forced slum evictions.

The structural injunction, however, cannot operate in a vacuum. Just like the success of social rights litigation, the success of this remedy is believed largely to be contingent on a favourable political context ${ }^{167}$; on a strong support structure, consisting of vigilant rightsadvocacy lawyers or organizations and responsive enforcement agencies ready to initiate legal mobilization; and also on a shift in the political culture. ${ }^{168}$ The situation of Bangladesh is challenging, as the court faces persistent confrontation with the political executives, ${ }^{169}$ who may refuse to respond even to the structural injunction. The court, therefore, should innovate ways of effectively collaborating with these actors while ordering the structural injunction. Such a judicial role is much needed in a state like Bangladesh, where the social inequality and injustice experienced by slum dwellers has thus far prevailed over any demonstration of the

164. Campaign for Popular Education (CAMPE) and Another v. Bangladesh [2012].

165. Young, supra note 130.

166. Hoque, supra note 10, p. 412.

167. Landau, supra note 88, p. 11.

168. Epp (1998), pp. 18-19.

169. Ahmed (2006), p. 103; Khan, supra note 140, pp. 266-9. 
constitutional commitment to ensure social justice and equality to those affected by state-initiated hostile evictions of slums.

\section{REFERENCES}

Ahmed, Farah, \& Tarunabh Khaitan (2015) "Constitutional Avoidance in Social Rights Adjudication." 35 Oxford Journal of Legal Studies 607-25.

Ahmed, Naim (1999) Public Interest Litigation: Constitutional Issus and Remedies, Dhaka: Bangladesh Legal Aid and Services Trust.

Ahmed, Nizam (2006) "Executive-Judiciary Relations in Bangladesh." 33(2) Asian Affairs 103-22.

Ain o Salish Kendra (2012) ASK in Defence of Human Rights 2012, Dhaka: Ain o Salish Kendra.

Ashutosh Sarker (2013) "Food Courts Still Stuck in Red Tape," The Daily Star, 2 November, <http:// www.thedailystar.net/news/food-courts-still-stuck-in-red-tape> (accessed 20 May 2017).

Baker, Judy, \& Nina Schuler (2004) "Analysing Urban Poverty: A Summary of Methods and Approaches," Policy Research Working Paper No. 3399, Washington, DC: World Bank, <https:// openknowledge.worldbank.org/handle/10986/14244> (accessed 24 May 2017).

Bangladesh Bureau of Statistics (2015) Preliminary Report on Census of Slum Areas and Floating Population 2014, Dhaka: Bangladesh Bureau of Statistics.

Birchfield, Lauren, \& Jessica Corsi (2010) "Between Starvation and Globalization: Realizing the Right to Food in India." 31 Michigan Journal of International Law 691-763.

CESCR General Comment No. 4 (1992) "The Right to Adequate Housing (Art. 11(1) of the Covenant)." E/1992/23, 13 December 1991.

CESCR General Comment No. 7 (1997) "The Right to Adequate Housing (Art. 11(1): Forced Evictions)." E/1998/22, 20 May.

CESCR General Comment No. 9 (1998) "The Domestic Application of the Covenant.” E/C.12/1998/ 24, 3 December.

Chapman, Audrey R. (1996) “A 'Violations Approach' for Monitoring the International Covenant on Economic, Social and Cultural Rights." 18 Human Right Quarterly 23-66.

Chayes, Abram (1976) "The Role of the Judge in Public Law Litigation." 89 Harvard Law Review 1281-1316.

Chenwi, Lilian (2008) Evictions in South Africa: Relevant International and National Standards, Bellville: Community Law Centre, University of the Western Cape.

Chenwi, Lilian (2009) "A New Approach to Remedies in Socio-Economic Rights Adjudication." 2 Constitutional Court Review 371-93.

COHRE \& ACHR (2000) "Forced Evictions in Bangladesh: We Didn't Stand a Chance," <https://docs. escr-net.org/usr_doc/COHRE__Forced_evictions.pdf $>$ (accessed 23 May 2017).

Cross, Frank B. (2001) "The Error of Positive Rights." 48 UCLA Law Review 857-924.

Currie, Iain, \& Johan De Wall (2005) The Bill of Rights Handbook, Johannesburg: Juta and Co.

Dhaka Tribune (2014) "300 Slums Evicted in Chittagong," 14 October, <http://www.dhakatribune. com/bangladesh/2014/oct/14/300-slums-evicted-chittagong > (accessed 25 May 2017).

Deng, Francis M (1998) Report of the Representative of the Secretary General Submitted Pursuant to Commission Resolution 1997/39, UN Doc. E/CN.4/1998/Add.2, 11 February.

Dixon, Rosalind (2007) "Creating Dialogue about Socioeconomic Rights: Strong Form versus Weak Form Judicial Review Revisited." 5 International Journal of Constitutional Law 391-418.

Dustha Shasthya Kendra and Shiree (2011) "Eviction and the Challenges in Protecting the Gains: A Case Study of Slum Dwellers in Dhaka City," <https://assets.publishing.service.gov.uk/media/ 57a08ac8ed915d622c0008e3/Shiree-WP3.pdf > (accessed 4 June 2017).

Ebadolahi, Mitra (2008) "Using Structural Interdicts and the South African Human Rights Commission to Achieve Judicial Enforcement of Economic and Social Rights in South Africa." 83 New York University Law Review 1565-1606. 
Eerd, Maartje Van, \& Banasree Banerjee (2013) Evictions, Acquisition, Expropriation and Compensation: Practices and Selected Case Studies, Working Paper No. I, UN-Habitat and Global Land Tool Network.

Epp, Charles R (1998) The Rights Revolution: Lawyers, Activists, and Supreme Courts in Comparative Perspective, Chicago: University of Chicago Press.

Feeley, Malcolm M., \& Van Swearingen (2004) "The Prison Condition Cases and the Bureaucratization of American Corrections: Influences, Impacts and Implications." 24 Pace Law Review 433-75.

Fiss, Owen M. (1979) "The Forms of Justice." 93 Harvard Law Review 1-58.

Frug, Gerald E. (1978) "The Judicial Power of the Purse." 126 University of Pennsylvania Law Review 715-94.

Gafur, Shayer (2004) "Human Development: Policy Implications for Homelessness in Bangladesh." 26 International Development Planning Review 261-86.

Garavito, Cesar Rodriguez (2011) "Beyond the Courtroom: The Impact of Judicial Activism on Socioeconomic Rights in Latin America." 87 Texas Law Review 1669-98.

Gillespie, Nora (1989-90) "Charter Remedies: The Structural Injunction." 11 Advocates Quarterly 190-221.

Gloppen, Siri (2006) "Courts and Social Transformation: An Analytical Framework," in R. Gargarella, P. Domingo, \& T. Roux, eds., Courts and Social Transformation in New Democracies: An Institutional Voice for the Poor?, Aldershot/Burlington: Ashgate, 35-59.

Gloppen, Siri (2008) "Public Interest Litigation, Social Rights and Social Policy," in A. Dani \& A. De Haan, eds., Inclusive States: Social Policy and Structural Inequalities, Washington, DC: World Bank, 343-67.

Guhathakurta, Meghna, \& Suraiya Begum (2005) "Bangladesh: Displaced and Dispossessed," in P. Banerjee, S. B. R. Chaudhury, \& S. K. Das, Internal Displacement in South Asia: The Relevance of the UN's Guiding Principles, New Delhi: Sage Publications, 175-212.

Haque, Mohammad Ekramul (2005) "Legal and Constitutional Status of the Fundamental Principles of State Policy as Embodied in the Constitution of Bangladesh." 16 Dhaka University Studies Part-F 45-80.

Hirsch, Danielle Elyce (2007) "A Defense of Structural Injunctive Remedies in South African Law." 9 Oregon Review of International Law 1-66.

Hohmann, Jessie (2013) The Right to Housing: Law, Concepts and Possibilities, Oxford: Hart.

Hoque, Ridwanul (2006) "Taking Justice Seriously: Judicial Public Interest and Constitutional Activism in Bangladesh." 15 Contemporary South Asia 399-422.

Hossain, Kamal (2005) "Realizing Rights: The Rights of the Slum Dwellers to Adequate Housing," in S. Islam, ed., Rights of Slum Dwellers: Permanent Settlement for the Urban Poor, Dhaka: Bangladesh Legal Aid and Services Trust, 13-16.

Hossain, Sara, \& Dina M. Siddiqi, eds. (2007) Human Rights in Bangladesh 2007, Dhaka: Ain o Salish Kendra.

International Commission of Jurists (2008) Courts and Legal Enforcement of Economic, Social and Cultural Rights: Comparative Experiences of Justiciability, Human Rights and Rule of Law Series: No. 2, Geneva.

Islam, Farzana (2006) "Right to Shelter," < http://www.askbd.org/ask/right-shelter/ > (accessed 16 June 2017).

Islam, Mohammad Nazrul (2003) "Slum Eviction and Housing Rights in Dhaka City (1975-2001)." 55 Japanese Journal of Human Geography 564-89.

Khan, Abeeda Aziz (2012) "NGOs, the Judiciary and Rights in Bangladesh: Just another Face of Partisan Politics." 1 Cambridge Journal of International Law 254-74.

Khera, Reetika (2006) "Mid-Day Meals in Primary Schools: Achievements and Challenges." 18 Economic and Political Weekly 4742-50.

Khosla, Madhav (2010) "Making Social Rights Conditional: Lessons from India." 8 International Journal of Constitutional Law 739-65.

King, Jeff (2012) Judging Social Rights, New York: Cambridge University Press. 
Kothari, Miloon (2007) Report of the Special Rapporteur on Adequate Housing as a Component of the Right to an Adequate Standard of Living, UN Doc A/HRC/4/18, 5 February.

Landau, David (2012) "The Reality of Social Rights Enforcement." 53 Harvard International Law Journal 189-247.

Langford, Malcolm (2009) "Domestic Adjudication of Economic, Social and Cultural Rights: A Socio-Legal Review." 6 SUR-International Journal of Human Rights 91-121.

Leckie, Scott (2003) National Perspectives on Housing Rights, The Hague, London: Martinus Nijhoff.

Mahbubul Haque Human Development Centre (2014) "Human Development in South Asia 2014: Urbanisation Challenges and Opportunities," http://mhhdc.org/wp-content/themes/mhdc/reports/ SAHDR_2014_Urbanization_Challenges_and_Opportunities.pdf (accessed 25 June 2017).

Mbazira, Cristopher (2008) You are the Weakest Link in Realizing Socio-economic Rights: GoodbyeStrategies for Effective Implementation of the Court Orders in South Africa, Bellville: Community Law Centre, University of Western Cape.

Mbazira, Christopher (2009) Litigating Socio-economic Rights in South Africa: A Choice between Distributive and Corrective Justice, Pretoria: Pretoria University Press.

Melish, Tara J. (2006) "Rethinking the 'Less as More' Thesis: Supranational Litigation of Economic, Social and Cultural Rights in the Americas." 39 New York University Journal of International Law and Politics 171-343.

Michelman, Frank I. (2003) "The Constitution, Social Rights and Liberal-Political Justification." 1 International Journal of Constitutional Law 13-34.

OHCHR (1996) "Fact Sheet No. 25, Forced Evictions and Human Rights," <http://www.ohchr.org/ Documents/Publications/FactSheet25en.pdf $>$ (accessed 23 May 2017).

Paul, Bimal Kanti (2006) "Fear of Eviction: The Case of Slum and Squatter Dwellers in Dhaka, Bangladesh." 27 Urban Geography 567-74.

Pereira, Faustina (2014) "When the Will is Far from the Way: Rising Concern over Non-implementation of Court Judgement," in Ain o Salish Kendra, ed., Rights and Remedies, 2nd ed., Dhaka: Ain o Salish Kendra, 69-78.

Pieterse, Marius (2004) "Coming to Terms with Judicial Enforcement of Socio-economic Rights." 20 South African Journal on Human Rights 383-417.

Pillay, Anashri, \& Murray Wesson (2014) "Recession, Recovery and Service Delivery: Political and Judicial Responses to the Financial and Economic Crisis in South Africa," in A. Nolan, ed., Economic and Social Rights after the Global Financial Crisis, Cambridge: Cambridge University Press, 335-65.

Pinheiro, Paulo Sérgio (2005) Housing and Property Restitution in the Context of the Return of Refugees and Internally Displaced Persons, UN Doc E/CN.4/Sub.2/2005/17/Add.1, 11 July.

Porter, Bruce (2005) "The Crisis of Economic, Social and Cultural Rights and Strategies for Addressing It," in J. Squires, M. Langford, \& B. Thiele, eds., The Road to Remedy: Current Issues in the Litigation on Economic, Social and Cultural Rights, Sydney: Australian Human Rights Centre, The University of New South Wales; Geneva: Centre for Housing Rights and Evictions, 43-69.

Rahman, Mohammad Mahbubur (2001) "Bastee Eviction and Housing Rights: A Case of Dhaka, Bangladesh.” 25 Habitat International 49-67.

Roach, Kent (2008) "The Challenges of Crafting Remedies for Violations of Socio-economic Rights," in M. Langford, ed., Social Rights Jurisprudence: Emerging Trends in International and Comparative Law, Cambridge: Cambridge University Press, 111-26.

Roach, Kent, \& Geoff Budlender (2005) "Mandatory Relief and Supervisory Jurisdiction: When Is It Appropriate, Just and Equitable." 122 South African Law Journal 325-51.

Roy, Debraj, et al. (2014) "The Emergence of Slums: A Contemporary View on Simulation Models." 59 Environmental Modelling and Software 76-90.

Schutter, Olivier De (2009) Large-scale Land Acquisitions and Leases: A Set of Minimum Principles and Measures to Address the Human Rights Challenge, UN Doc A/HRC/13/33/Add.2, 28 December.

Sepulveda, M. Magdalena, (2003) The Nature of Obligations under International Covenant on Economic, Social and Cultural Rights, Utrecht: Intersentia. 
Shetreet, Shimon (1988) "Judging in Society: The Changing Role of Courts," in S. Shetreet, ed., The Role of Courts in Society, Dordrecht: Martinus Nijhoff, 467-86.

Shiree and Dustha Shasthya Kendra (DSK) (2012) "Moving Backwards: Korail Slum Eviction," $<$ https://assets.publishing.service.gov.uk/media/57a08a9aed915d622c0007f7/Korail-EvictionReport.pdf $>$ (accessed 11 June 2017).

Steiner, Philip, Ryan Goodman, \& Henry J. Steiner (2008) International Human Rights in Context: Law, Politics and Morals: Text and Materials, 3rd edn, New York: Oxford University Press.

Sunstein, Cass R (2000-2001) "Social and Economic Rights: Lessons from South Africa." 11 Forum Constitutional 123-32.

Swart, Mia (2005) "Left Out in the Cold: Crafting Constitutional Remedies for the Poorest of the Poor." 21 South African Journal on Human Rights 215-40.

Tipple, Graham, \& Suzanne Speak (2005) "Definitions of Homelessness in Developing Countries." 29 Habitat International 337-52.

Tushnet, Mark (2004) "Social Welfare Rights and the Forms of Judicial Review." 82 Texas Law Review 1895-1919.

UN-Habitat (2007) "Report on Human Settlements 2007: Enhancing Urban Safety and Security," $<$ https://www.un.org/ruleoflaw/files/urbansafetyandsecurity.pdf $>$ (accessed 23 June 2017).

UN-Habitat (2011) “A Mission For the $21^{\text {st }}$ Century," <http://mirror.unhabitat.org/pmss/get ElectronicVersion.aspx?nr=3097\&alt=1 > (accessed 17 May 2017).

UN-Habitat (2016) "Urbanisation and Development: Emerging Futures," <http://unhabitat.org/wp content/uploads/2014/03/WCR-\%20Full-Report-2016.pdf> (accessed 2 June 2017).

UN-Habitat \& UNHCR (2014) "Forced Evictions, Fact Sheet No 25, Rev.1," < http://www.ohchr.org/ Documents/Publications/FS25.Rev.1.pdf $>$ (accessed 7 May 2017).

UNCHR (1993) Forced Evictions, UN Doc E/CN.4/RES/1993/77, 10 March.

UNDP (2013) The Gopalganj Housing Model: A Way Forward for Community Driven Affordable Urban Housing, Dhaka: UNDP.

United Nations (2000) "We the Peoples: The Role of the United Nations in the $21^{\text {st }}$ Century," < http:// www.un.org/en/events/pastevents/pdfs/We_The_Peoples.pdf > (accessed 15 April 2017).

Wesson, Murray (2004) "Grootboom and Beyond: Reassessing the Socio-economic Jurisprudence of the South African Constitutional Court." 20 South African Journal on Human Rights 284-308.

World Bank (2007) Dhaka: Improving Living Conditions for the Urban Poor, Bangladesh Development Series Paper No 17.

Young, Katharine G (2012) Constituting Economic and Social Rights, New York: Oxford University Press.

\section{CASE-LAW}

Argentina

Mendoza, Beatriz et al v. the Argentine Government et al for harms, M.1569.XL, 8 July 2008.

Bangladesh

Ain o Salish Kendra (ASK) and Others v. Government of Bangladesh and Others [1999] 19 BLD 488 (HCD).

Ain o Salish Kendra and Another v. Bangladesh [2011] 63 DLR 95 (HCD).

Aleya Begum v. Bangladesh and Others [2001] 53 DLR 63 (HCD).

BLAST and Others v. Government of the People's Republic of Bangladesh and Others [2008] 60 DLR 749 (HCD).

BLAST v. Bangladesh [2005] 25 BLD 83 (HCD).

BLAST and Others v. Government of Bangladesh [2008] 60 DLR 749 (HCD).

Campaign for Popular Education (CAMPE) and Another v. Bangladesh [2012] Writ Petition No. 312.

Dr Mohiuddin Farooque v. Bangladesh and Others [1997] 49 DLR 1 (AD).

Dr Mohiuddin Farooque v. Bangladesh [2003] 55 DLR 69 (HCD). 
Faustina Pereira v. State [2001] 53 DLR 414 (HCD).

Human Rights and Peace for Bangladesh v. Bangladesh [2009] 30 BLD 125 (HCD).

Kalam and Others v. Bangladesh and Others [2001] 21 BLD 446 (HCD).

Kudrat-E-Elahi v. Bangladesh [1992] 44 DLR 319 (AD).

Modhumala v. Bangladesh [2001] 53 DLR 540 (HCD).

Masdar Hossain v. Secretary, Ministry of Finance [1998] 18 BLD 558 (HCD).

Secretary, Ministry of Finance v. Masdar Hossain [2000] 52 DLR 82 (AD).

Siddique Ahmed v. Government of Bangladesh and Others [2013] 65 DLR 8 (2013) (AD).

Canada

Doucet-Boudreau v. Nova Scotia (Minister of Education) [2003] 3 SCR 3.

Elridge v. British Columbia [1997] 151 DLR $\left(4^{\text {th }}\right) 577$.

Lavoie v. Nova Scotia [1988] 47 DLR $\left(4^{\text {th }}\right) 586$.

Marchand v. Simcoe Country Board of Education [1986] 29 DLR $\left(4^{\text {th }}\right) 596$.

Colombia

Decision T-025/04 [2004] (Colombian Constitutional Court).

India

Olga Tellis and Others v. Bombay Municipal Corporation [1985] 3 SCC 545.

People's Union of Civil Liberties v. Union of India [2007] 12 SCC 135.

Sheela Barse v. Union of India and Others [1988] 4 SCC 226.

South Africa

August and Another v. Electoral Commission and Other [1999] (3) SA 1 (CC).

Blue Moonlight Properties v. The Occupiers of Saratoga Avenue and Others [2009] 1 SA 470.

Fose v. Minister of Safety and Security [1997] 7 BCLR 851 (CC).

Government of the Republic of South Africa and Others v. Grootboom and Others [2000] 11 BCLR 1169.

Minister of Health v. Treatment Action Campaign [2002] 5 SA 721 (CC).

Magidimisi v. Premier of the Eastern Cape and Others [2006] ZAECHC 20.

Ngxuza and Others v. Permanent Secretary, Department of Welfare, Eastern Cape and Another [2001]

2 SA 609.

Occupiers of 51 Olivia Road and Others v. City of Johannesburg and Others [2008] 5 BCLR 475 (CC).

Pheko and Others v. Ekurhuleni Metropolitan Municipality [2012] 42 SA 598 (CC).

Sailing Queen Investments v. The Occupiers La Colleen Court [2008] 6 BCLR 666.

Schubart Park Residents Association and Others v. City of Tshwane Metropolitan Municipality and Others [2013] 1 SA 323 (CC).

Sibiya and Others v. Director of Public Prosecution Johannesburg and Others (2005) (5) SA 315 (CC).

Treatment Action Campaign v. Minister of Health [2002] 4 BCLR 356 (T).

United States

Brown v. Board of Education [1955] 349 US 294.

Bell v. Wolfish [1979] 441 US 520.

Hutto v. Finney [1978] 437 US 678.

Pasadena City Board of Education v. Spangler [1976] 427 US 424.

Reynolds v. Sims [1964] 377 US 533.

Swann v. Charlotte-Mecklenburg Board of Education [1971] 402 US 1. 